\title{
LSTM Tabanlı Derin Sinir Ağı ile Beşinci Nesil Küçük Hücre Ağlarında El Değiștirme Tahmini
}

\section{Handover Prediction in Fifth Generation Small Cell Networks with LSTM-Based Deep Neural Network}

\author{
Murtaza Cicioğlu ${ }^{1 *}$ \\ Geliş / Received: 15/12/2020 \\ Revize / Revised: 04/01/2021 \\ Kabul / Accepted: 08/01/2021

\begin{abstract}
$\overline{\mathbf{O ̈ Z}}$
Bu çalışmada, Uzun Kısa-Vadeli Hafıza (LSTM) tabanlı derin sinir ağı ile beşinci nesil küçük hücre ağlarında el değiştirme (handover, HO) tahminlerini gerçekleştiren yeni bir model geliştirilmiştir. İlk olarak HO tahmininde eğitim için kullanılacak olan veri seti Riverbed Modeler benzetim yazılımında tasarlanan benzetim senaryoları ile oluşturulmuştur. Bu senaryolar aracılı̆̆ıly sinir ağının veri kümesinde kullanılacak üç adet giriş (RSSI, SNR ve Jitter) değişkeni ve bir adet çıkış (istenen değer) değişkeni elde edilmiş̧ir. Bu veri seti makine öğrenmesi algoritmalarından LSTM, SVM, Tree ve Lineer Regresyon teknikleri ile eğitilmiştir. LSTM tabanlı derin sinir ağı diğer regresyon algoritmaları ile karşılaş̧ırılmış ve daha yüksek başarıma sahip olduğu tespit edilmiştir. LSTM için eğitilen modelin test sonuçları incelendiğinde; $\mathrm{R}^{2} 0.94$, MAE 0.3315 , MSE 0.3670 ve RMSE değeri 0.6058 olarak bulunmuştur. LSTM tabanlı derin sinir ağlarının, regresyon işlemlerinde yüksek başarım gösterdiği
\end{abstract} \\ görülmüştür. Sonuç olarak önerilen regresyon modeli ile 5G küçük hücre ağlarında HO kararlarının tahmin \\ edilebildiği gösterilmiştir.
}

Anahtar Kelimeler-5G, Kü̧ü̈k Hücre, Makine Ö̆̆renmesi, LSTM

\begin{abstract}
In this study, a new model is developed that performs handover prediction in fifth generation small cell networks with Long Short Term Memory (LSTM) based deep neural networks. Firstly, the data set to be used for training in handover prediction was created with simulation scenarios designed in Riverbed Modeler. Through these scenarios, three input (RSSI, SNR and Jitter) variables and one output variable (desired value) were obtained to be used in the data set of the neural network. This data set was trained with machine learning algorithms LSTM, SVM, Tree, and Linear Regression techniques. LSTM-based deep neural network was compared with other regression algorithms and was found to have higher performance. When the test results of the trained model for LSTM are examined; $\mathrm{R}^{2} 0.94$, MAE 0.3315 , MSE 0.3670 , and RMSE value 0.6058 was found. It was observed that LSTM-based deep neural networks show high performance in regression processes. As a result, study shows that handover decisions can be predicted in 5G small cell networks with the proposed regression model.
\end{abstract}

\section{Keywords- 5G, Small Cell, Machine Learning, LSTM}

1*Sorumlu yazar iletişim: murtazacicioglu@uludag.edu.tr (https://orcid.org/0000-0002-5657-7402) Bilgisayar Mühendisliği Bölümü, Mühendislik Fakültesi, Bursa Uludağ Üniversitesi, Bursa, Türkiye 


\section{GíRiş}

Mobil veri trafiği her geçen yıl hızla artmakta, mevcut ağ altyapıları bu ihtiyaçlara cevap verme noktasında yetersiz kalmaktadır. İnternete bağlanan akıllı cihaz (telefonlar, tabletler vb.) sayısındaki üstel artış, kablosuz haberleşme altyapılarının performansını olumsuz etkilemektedir. Bu aşırı veri trafiği servis sağlayıcıları üstünde de ciddi bir baskı oluşturmaktadır. Mobil kullanıcı ihtiyaçlarının kabul edilebilir seviyede karşılanabilmesi için yaratıcı, düşük maliyetli ve hızlı uygulanabilir yeni çözümlere ihtiyaç duyulduğu görülmektedir. Beşinci Nesil (5th Generation, 5G) ağ mimarisinin gerçek ortamlarda uygulanabilmesi, tüm dünyada olduğu gibi ülkemizde de yeni nesil kablosuz haberleşme için en önemli hedefler arasındadır [1]-[3].

Ericsson şirketinin 2020 hareketlilik raporunda, 2026 yılına kadar toplam mobil verilerinin tahmini yüzde 54'ünü 5G teknolojisinin oluşturacağı öngörülmektedir [4]. Bu sonuç Şekil 1'de ayrıntılı olarak verilmiştir. 5G teknolojisi için günümüz hücresel ağlarda kullanılan düşük ve orta bant tayfları servis kalite gereksinimlerinin karşılanabilmesi açısından oldukça yetersizdir. Bu nedenle küçük hücreler şeklinde kablosuz ağ kurulmasına ve kısa mesafelerde yüksek veri taşıma kapasitesine sahip yüksek bant tayflarına ihtiyaç duyulmaktadır. 5G teknolojisinin tüm dünyada yaygınlaşabilmesi düşük kapsama alanlarına sahip çok fazla sayıda erişim noktalarının kurulumları ile mümkün olacaktır. Bu bakımdan küçük hücreler $5 \mathrm{G}$ teknolojisinin yaygınlaşabilmesi için en kritik noktalardan biri olarak görülmektedir. Küçük hücre ağlarının yaygınlaştırılması ve performanslarının iyileştirilmesi geleceğin kablosuz haberleşme hedefleri arasındadır [5].

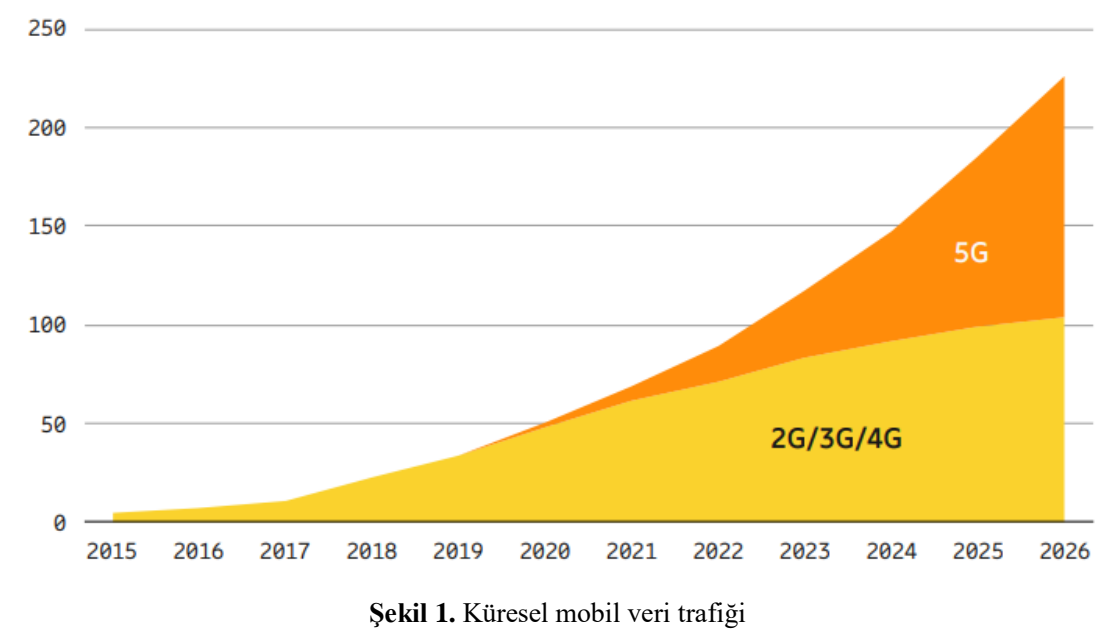

Günümüz ağ altyapıları geniş kapsama alanına sahip makro hücrelerden (macro cells) oluşmaktadır. Ancak alışveriş merkezleri, stadyumlar, ulaşım istasyonları gibi özel ve yoğun ağ senaryoları düşünüldüğünde bu altyapıların kapsama ve kapasite açısından yetersiz ve verimsiz olduğu görülmektedir. Bu nedenle kapasite ve kapsama alanın arttırılması kaçınılmaz bir ihtiyaca dönüşmüştür. Bu noktada iki farklı çözüm önerilebilmektedir. Bu çözüm önerilerinden ilki, ortama daha fazla baz istasyonu ekleyerek daha yoğun ağ ortamları oluşturmak, bir diğer çözüm önerisi ise daha fazla tayf tahsisi gerçekleştirmektir. Bu çözümlerden ikincisi için 4G teknolojisinin gelişimi ve iyileştirilmesi çalışmalarında tayf aralıkları, bant geniş̧likleri ile ilgili çalışmalar yapılmış ancak yine de yeterli olmadığı tespit edilmiştir. Ayrıca bu çözümün de oldukça maliyet gerektirmesi de bir diğer dezavantaj olarak karşımıza çıkmaktadır. Bu nedenle aşırı yoğun ağ (ultra-dense network, UDN) olarak isimlendirilen ilk önerinin daha uygun bir çözüm olduğu görülmektedir. UDN çok sayıda küçük hücrelerin çeşitli noktalara kurulumu ve dağıtık anten sistemleri ile gerçekleşebilmektedir. Ağın yoğunlaştırılması yaklaşımı kapasite ve kapsama alanının arttırılması konusunda başarılı sonuçlar vermektedir [6].

Geleneksel baz istasyonlarının tüm özelliklerine sahip küçük hücreler, mobil kullanıcıları küçük coğrafi alanlar üzerinden mobil ağlara bağlayan, kısa menzilli radyo erişim noktalarıdır. Farklı güç seviyesi ve kapsama alanına göre femtocells, picocells ve microcells olarak isimlendirilen bu baz istasyonlarının tamamı küçük hücreler (small cell) olarak genellenebilir. Küçük hücreler makro hücrelerin yetersiz kaldığı, yüksek veri kapasitesi ve kapsama alanı ihtiyacı olan aşırı yoğun kentsel alanlarda kurulması öngörülmektedir. 
Hücresel kablosuz haberleşme ağlarında, mobil kullanıcıların (MK) hareketlilik gereksinimleri el değiştirme (handover - HO) mekanizması ile sağlanabilmektedir [7]-[9]. Bu sayede MK hareket halindeyken ağın kapsama alanı içinde ya da dışında kesintisiz olarak haberleşmesini sürdürebilmektedir. HO mekanizması, bir küçük hücre baz istasyonu (eNB) tarafından sürdürülen bir oturumun komşu bir hücreye yeniden atanması işlemidir. MK bağlantı kurmaya çalıştığında baz istasyonları ilgili haberleşme sinyalleri ile gerekli kaynakları atamaktadır. HO işleminden dolayı MK ve baz istasyonları arasında oluşan paket alış verişleri ağ yüküne, gecikmelere ve paket kayıplarına sebep olabilmektedir. Bu nedenle geliştirilecek HO algoritmalarının bu sorunlara çözüm bulması beklenmektedir. 5G küçük hücre ağlarının en önemli konulardan biri de HO yönetiminin etkili ve verimli bir şekilde gerçekleştirilebilmesidir.

Son zamanlarda Makine Öğrenimi (MÖ) ve farklı bilişsel teknikler çeşitli ağ teknolojilerine uygulanmakta ve daha otonom, akıllı ve dinamik mimariler geliştirilmektedir [10]-[14]. Aljeri ve Boukerche [14] çalışmalarında HO yönetimi için iki katmanlı makine öğrenmesine dayalı yeni bir yaklaşım önermişlerdir. İlk olarak HO tetikleme kararını türetmek için erişim noktalarının alıcı sinyal gücünü tahmin eden tekrarlayan bir sinir ağı modeli kullanılmıştır. Akabinde bir sonraki erişim noktasını seçmek için bir Markov modeli geliştirilmiştir. Ensar Zeljkovi' vd. [15] çalışmalarında MÖ destekli bir HO algoritması (ABRAHAM) geliştirmişlerdir. Bu çalışmada MK ile ağ geçidi arasındaki bağlantı kalitesini tahmin edebilen LSTM ağı modellemişlerdir. Yao Sun vd. HO yönetiminden dolayı oluşan maliyetleri en aza indirebilmek amacıyla güçlendirilmiş dağıtık öğrenme yaklaşımına dayalı akıllı HO yönetimi (LESS) önermişlerdir [16]. Aşırı yoğun ağ ortamlarında geleneksel HO algoritmaları ile hareketlilik yönetimi hem oldukça zor hem de karmaşıklığa sebep olmaktadır. Bu soruna çözüm olarak MÖ tekniklerinden yararlanılması oldukça önemlidir. Bu sayede dinamik ağ koşullarında uygun HO kararlarının verilebilmesi mümkün olacaktır. Geleneksel yaklaşımda HO yönetimi için sadece Alınan Sinyal Gücü Göstergesi (Received Signal Strength Indication, RSSI) parametresi kullanılmaktadır. Ancak daha güvenilir HO yönetimi için RSSI parametresinin yanı sıra Sinyal-Gürültü Oranı (Signal-to-Noise Ratio, SNR) ve Jitter gibi daha önemli parametrelerden de yararlanılabilir. Jitter gecikmedeki değişiklik veya sinyalin iletilmesi ile alınması arasındaki zaman gecikmesi olarak ifade edilmektedir.

Geleneksel HO yönetiminde (3G/4G) en yüksek veri hızı, kapsama alanı ve tayf verimliliği gibi daha net metrikler ile daha çok ağ odaklı bir başarıma odaklanılmıştır. Bu nedenle MK'ların deneyim kalitesi olarak ifade edilen QoE (quality of experience) beklentileri ihmal edilmiştir. 5G teknolojisinin hücresel ağları için öne sürdüğü en önemli yeniliklerden biri kullanıcı odaklı ve veriye dayalı akıllı ağ algoritmalarının geliştirilmesidir. Buradaki en önemli amaç ağ kaynaklarının kullanımını optimize etmek ve MK'ların QoE beklentilerini karşılayabilmektir. Bu beklentilerin karşılanabilmesi a ğ ortamında daha fazla verinin toplanması ve en uygun kararları verebilen akıllı algoritmaların geliştirilmesi ile mümkündür. Önerdiğimiz makine öğrenmesi temelli HO yaklaşımı bu beklentilerin karşılanabilmesi için 5G küçük hücre ağlarının ă̆ ortamı ile ilgili verileri analiz edebilme yaklaşımına dayanmaktadır. Bu çalışmada 5G küçük hücre ağlarında makine öğrenmesi kullanılarak çok metrikli HO kararlarını tahmin edebilen yeni bir model geliştirilmiştir.

\section{SISTEM MODELI}

5G küçük hücre ağlarında HO kararlarını önceden tahmin edebilmeyi amaçlayan yeni bir tekrarlayan sinir ağı (RNN), daha özelde uzun kısa süreli bellek (LSTM) modeli geliştirilmiştir. Önerilen algoritmayı doğrulamak ve değerlendirmek için SVM, Tree ve Lineer regresyon algoritmaları ile karşılaştırılmıştır. Bu çalışmada Riverbed Modeler ve MATLAB benzetim yazılımlarından yararlanılmıştır.

\section{A. Makine Öğrenmesi ve Uzun Kısa Vadeli Bellek (LSTM)}

Yapay zeka tekniklerinden doğan MÖ, geliştirilen sistemin eğitim verilerinden faydalı yapısal kalıp ve modelleri öğrenmesine imkan tanıyan bir yaklaşımdır. MÖ genellikle eğitim ve karar verme olmak üzere iki ana kısımdan oluşur. İlk olarak eğitim veri kümesi kullanılarak sistem modelini öğrenmek için ML yöntemlerinin uygulandığı eğitim aşaması ve daha sonra sistem eğitimli modeli kullanılarak her yeni girdi için tahmini çıktıyı elde edebilen karar verme aşamalarından oluşmaktadır. MÖ algoritmaları denetimli, denetimsiz ve takviyeli olmak üzere üç kısımda ele alınır. MÖ ile ilgili daha detaylı bilgi almak için ilgili kaynakçanın incelenmesi tavsiye edilir [17].

Sinir ağları (Neural Networks, NN) ise geçmiş verilerden deneysel bilgiyi öğrenmek için paralel olarak çalışan çok sayıda basit işlem birimlerinden oluşmaktadır. İnsan beyninden esinlenmiş olan bu algoritma, doğrusal olmayan ve paralel hesaplamalar gerçekleştirebilmek için nöronlar olarak bilinen temel bileşenleri kullanmaktadır. 
Sinir ağlarında ifade edilen düğümler insan beynindeki nöronların ilkel bir modelidir [18]. Bu düğümler aktivasyon işlevlerini kullanarak doğrusal olmayan hesaplamaları gerçekleştirebilmektedir. En sık kullanılan aktivasyon fonksiyonları sigmoid ve hiperbolik tanjant fonksiyonlarıdır. İnsan beynindeki nöronların birbiri ile bağlanma şeklini temel alan sinir ağlarındaki düğümler, değişken bağlantı ağırlıklandırmalarla birbirine bağlanmaktadır. Birçok katmana sahip sinir ağlarının ilk olarak giriş katmanı ve son olarak da çıktı katmanı bulunmaktadır. Giriş katmanı ile çıtı katmanı arasındaki diğer katmanlar ise gizli katmanlar olarak ifade edilmektedir. Her bir katmanın çıktısı bir sonraki katmanın girdisi olacak şekilde tasarlanır. Son katman ise sistemin çıktısı olarak görev görür. Sinir ağlarının performansı gizli katman sayılarının ve her bir katmandaki düğüm sayılarının arttırılıp azaltılması (deneme yanılma) ile iyileştirilir [12, 15, 19-21].

Literatürde ve MÖ uygulamalarında en yaygın kabul gören tekrarlayan sinir ağ LSTM mimarisidir. Bu mimari farklı zaman ve katmanlardan gelen hata değerini korurken, sabit bir hata değeri sağlayarak tekrarlayan ağların öğrenme adımlarının devam edebilmesini sağlamaktadır. Uzun vadeli bağımlılıkları yakalama konusunda iyi bir yeteneğe sahiptir. LSTM ağ modeli, gizli durumu hesaplamak için giriş, çıkış ve unutma olmak üzere üç adet geçit kullanır. LSTM hücresi verileri sıralı olarak işleyebilmekte ve zaman içinde gizli durumunu koruyabilmektedir.

Şekil 2'de çalışmamızda geliştirilen LSTM ağ mimarisi verilmiştir. A $\breve{g}$, bir dizi giriş katmanı, üç adet LSTM katmanı, tamamen bağlı katman ve bir regresyon çıktı katmanından oluşmaktadır. Giriş katmanında RSSI, SNR ve Jitter olmak üzere üç giriş değişkeni tanımlanmıştır. Regresyon çıktı katmanında ise sadece bir çıkış değişkeni tanımlanmıştır. LSTM katmanlarında sırasıyla 128, 64 ve 128 nöron kullanılmıştır. Şekil 3 'te ise tasarlanan LSTM ağ mimarisinin eğitim başarım sonuçları gösterilmiştir.

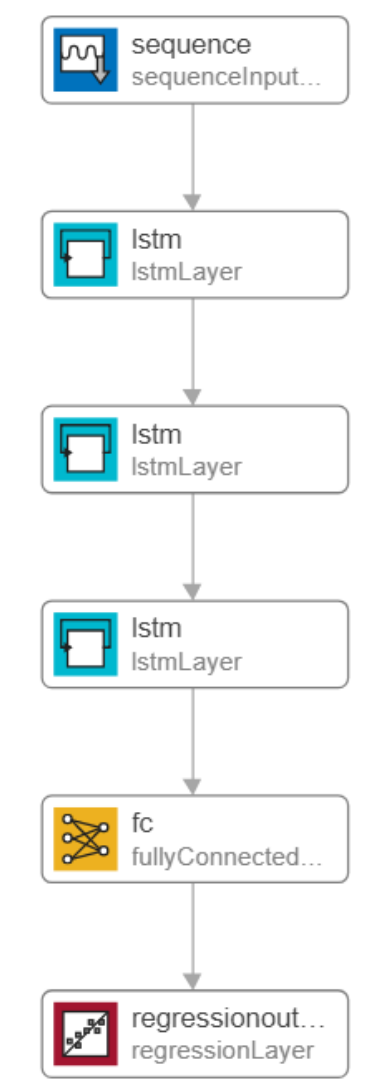

Şekil 2. Ĕgitim için geliştirilen ağ mimarisi 


\begin{tabular}{|c|c|c|}
\hline & $\begin{array}{l}\text { BŞEÜ Fen Bilimleri Dergisi } \\
8(1), 90-99,2021\end{array}$ & $\begin{array}{r}\text { BSEU Journal of Science } \\
\text { https://doi.org/10.35193/bseufbd.840927 }\end{array}$ \\
\hline ERS & & 2458-7575 (https://dergipark.org.tr/tr/pub/bseufbd) \\
\hline
\end{tabular}
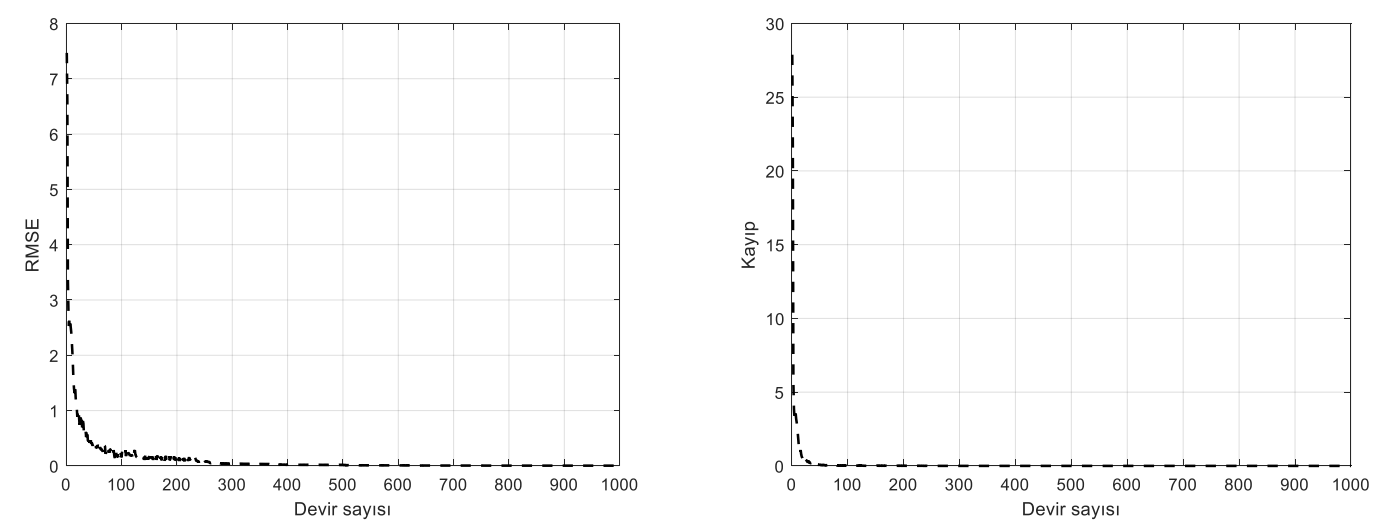

Şekil 3. LSTM mimarisin eğitim sonuçları

\section{B. Veri Setinin Hazırlanması}

Öğrenme tekniklerini kullanarak HO karar tahmini için veri setini almak, verileri formatlamak, sinir ağını tasarlamak, sinir ağını eğitmek ve ardından tahmine başlamak (veya ağı test etmek) şeklinde bir süreç sonunda mimari geliştirilmiştir. Gerçek değerlere kıyasla en iyi tahmin doğruluğunu elde etmek için her adım ayrıntılı olarak ele alınmıştır.

MÖ’de tahminin en önemli bölümü veri kümesidir. 5G küçük hücre ağında HO işlemi için literatürde açık kaynak bir veri setiyle karşılaşılmamıştır. Bu nedenle veri setinin hazırlanmasında Riverbed Modeler benzetim yazılımında oluşturulmuş çeşitli senaryolardan yararlanılmıştır. Çalışmamızda HO yönetimi için çok metrikli karar mekanizması kullanılacağından senaryolar buna uygun tasarlanmıştır. Bu sayede daha gerçekçi, bilgi açısından zengin ve açık kaynaklı bir veri seti oluşturulmuştur. Bu veri seti $5 \mathrm{G}$ küçük hücre ağlarında $\mathrm{HO}$ kararlarının tahmin edilebilmesi için meydana getirilmiştir. Şekil 4'te veri seti için Riverbed Modeler benzetim yazılımında tasarlanan örnek bir senaryo verilmiştir. MN1 isimli mobil düğüm ok ile gösterildiği gibi bir başlangıç ve bitiş noktaları arasındaki bir rotada sabit hızla hareket etmektedir. Bu hareketi esnasında etrafinda bulunan baz istasyonlarından periyodik aralıklarla RSSI, SNR ve Jitter verilerini içeren paketler almaktadır.

Veri seti RSSI, SNR ve Jitter değişkenlerini ve bu değişkenler sonucunda oluşan istenen değer bilgilerini içermektedir. Bu çalışmadaki en önemli yeniliklerden biri HO karar mekanizmasının geleneksel yaklaşımın aksine MÖ destekli olmasıdır.

Önerilen modelin başarımının tespiti için MATLAB yazılımı kullanılarak bir LSTM ağı tasarlanmıştır. Riverbed Modeler benzetim yazılımından elde edilen veri seti burada tasarlanan MÖ teknikleri ile eğitilmiştir. Tüm modelleri eğitmek için orijinal veri kümesinin yüzde 80'ini ayrılmıştır. Kalan yüzde 20'si ise ağın sağlamlığını test etmek için kullanılmıştır. 


\begin{tabular}{|c|c|c|}
\hline & $\begin{array}{l}\text { BŞEÜ Fen Bilimleri Dergisi } \\
8(1), 90-99,2021\end{array}$ & $\begin{array}{r}\text { BSEU Journal of Science } \\
\text { https://doi.org/10.35193/bseufbd.840927 }\end{array}$ \\
\hline ERS & & 2458-7575 (https://dergipark.org.tr/tr/pub/bseufbd) \\
\hline
\end{tabular}

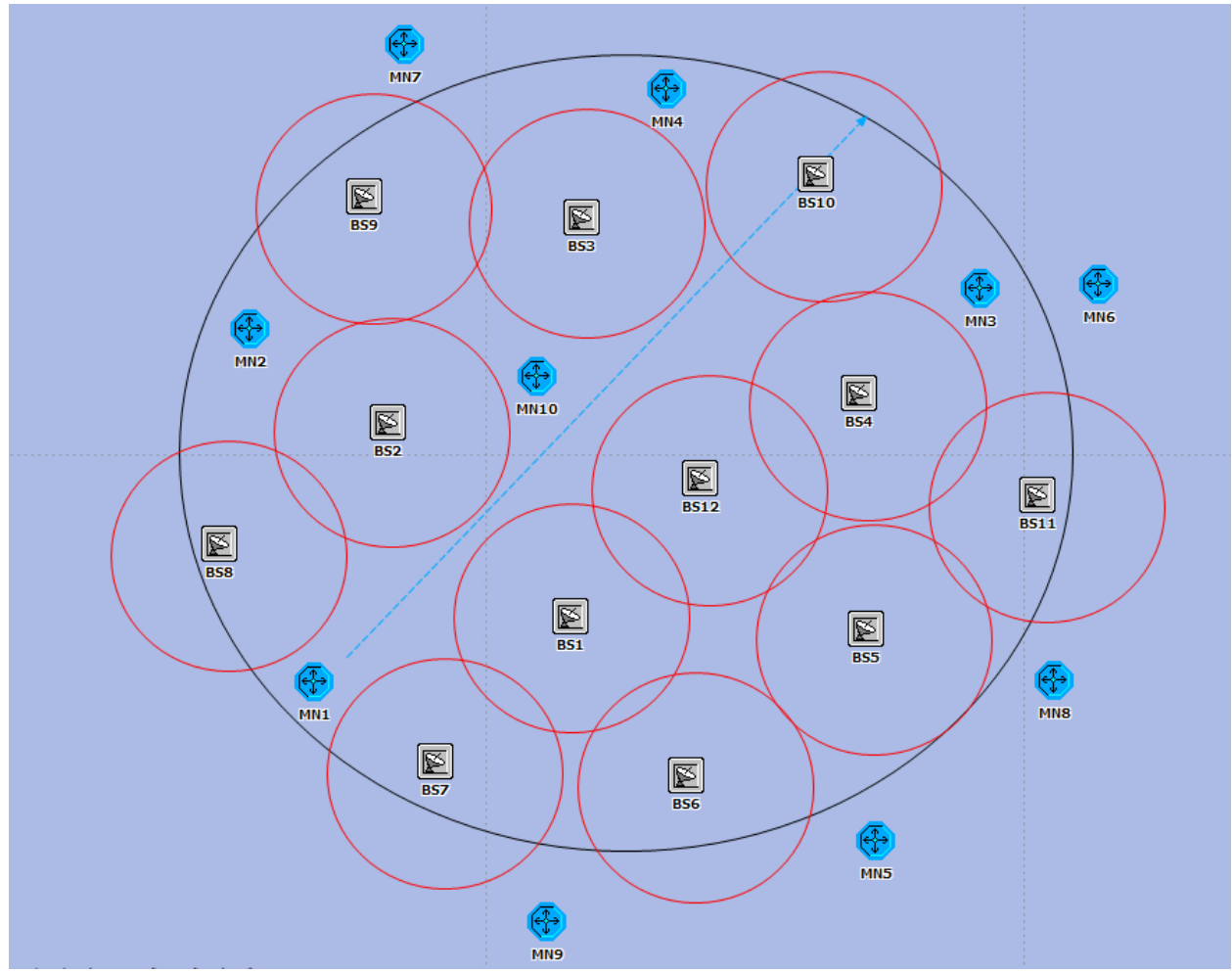

Şekil 4. Riverbed benzetim yazılımında veri seti oluşturmak için hazırlanan örnek bir senaryo

\section{BENZETIM SONUÇLARI}

5G küçük hücre ağlarında HO yönetimi için geliştirilen çok metrikli makine öğrenmesi tekniklerinin başarımını değerlendirmek amacıyla MATLAB yazılımı kullanılmıştır. MATLAB [22], makine öğrenmesi konusunda birçok desteğe sahip oldukça güçlü bir yazılımdır. Riverbed Modeler [23] ise haberleşme ağlarının modellenmesinde kullanılan, yaygın kabul görmüş nesne yönelimli bir benzetim yazılımıdır. Geliştirilen sistemin başarımı ayrık durum benzetimi ile yapılabilmektedir.

Tablo 1. LSTM ağ modelinin eğitim parametreleri

\begin{tabular}{lc}
\hline Hiper ve diğer parametreler & Değerler \\
\hline Eğitim verisi & 328 \\
Test verisi & 82 \\
Giriş & 3 \\
Çıkış & 1 \\
İterasyon sayısı & 1000 \\
Katman sayısı & 3 \\
Yığın (Batch) boyutu & 125 \\
Öğrenme hızı & 0.0300 \\
\hline
\end{tabular}

Tablo 1'de LSTM ağ modelinin eğitim için kullanılan parametreler detaylı olarak verilmiştir. Şekil 5'te LSTM ağ modelinden HO kararları için elde edilen tahmini aday değerler ile gerçek değerlerin karşılaştırıldığı başarım sonuçları gösterilmektedir. Elde edilen sonuçlar eğitilmiş LSTM ağ modelinin gerçek aday değerlere çok yakın tahminler ürettiğini göstermektedir. Bu sonuçlar, LSTM ağ modelinin HO karar tahminlerini oldukça iyi bir seviyede gerçekleştirebileceğini ispatlamaktadır. 


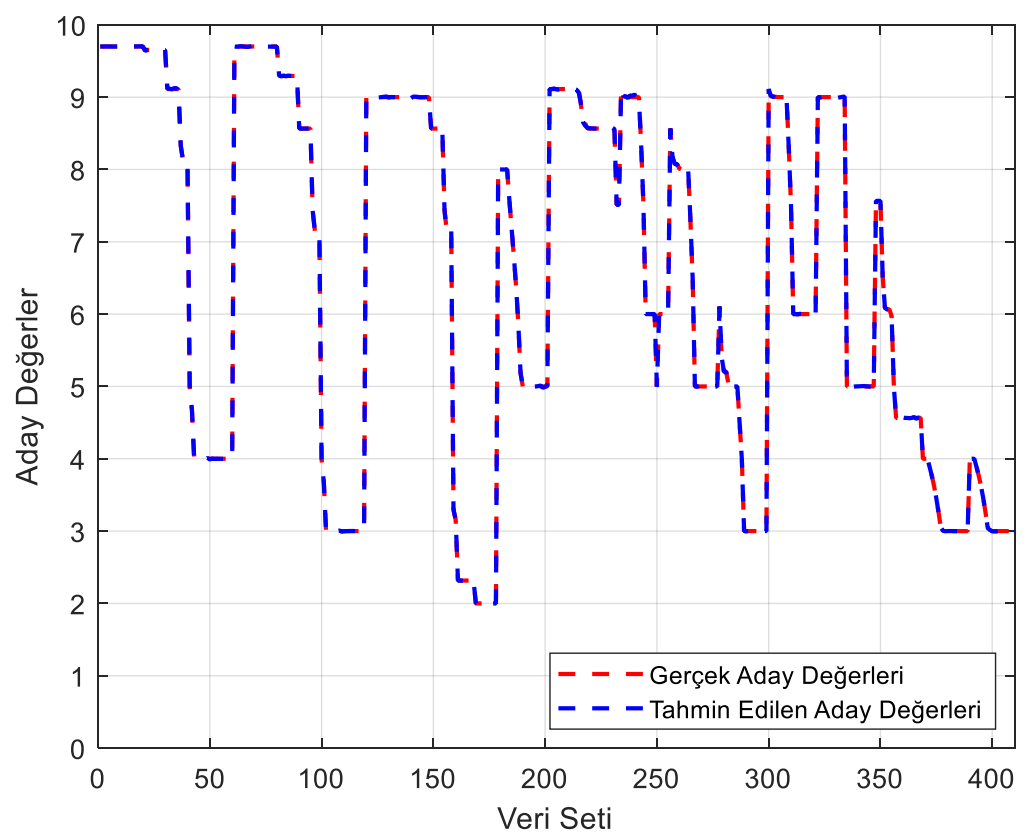

Şekil 5. LSTM modelinin başarım sonucu

Tablo 2'de ise kullanılan MÖ teknikleri (SVM, Tree, Lineer Reg.) ve bu tekniklerin başarım sonuçlarını içermektedir. LSTM ağının eğitim için $\mathrm{R}^{2}$ değeri 0.99, MAE değeri 0.0791, MSE değeri 0.0418 ve RMSE değeri 0.0633 olarak bulunmuştur. Yine LSTM ağının test için $\mathrm{R}^{2}$ değeri 0.94 , MAE değeri 0.3315 , MSE değeri 0.3670 ve RMSE değeri 0.6058 olarak bulunmuştur. Tablo 2'de SVM, Tree ve Lineer Regresyon için aynı veriler detaylıca verilmiştir. Elde edilen bu sonuçlar incelendiğinde en yüksek başarımın LSTM ağ modeli tarafından elde edildiğini göstermektedir. Bu nedenle HO karar tahminlerinde LSTM ağ modelinin kullanılması daha uygun görünmektedir.

Tablo 2. Eğitilen modellerin başarım değerleri

\begin{tabular}{ccccccccc}
\hline & \multicolumn{2}{c}{ RMSE } & \multicolumn{2}{c}{$\mathbf{R}^{2}$} & \multicolumn{2}{c}{ MAE } & \multicolumn{2}{c}{ MSE } \\
\hline & Eğitim & Test & Eğitim & Test & Eğitim & Test & Eğitim & Test \\
\hline LSTM & 0.0633 & 0.6058 & 0.99 & 0.94 & 0.0791 & 0.3315 & 0.0418 & 0.3670 \\
SVM & 1.3682 & 1.3124 & 0.73 & 0.71 & 1.0887 & 2.7534 & 1.8720 & 1.7223 \\
Tree & 0.7430 & 0.6934 & 0.92 & 0.92 & 0.5384 & 2.7347 & 0.5520 & 0.4809 \\
$\begin{array}{c}\text { Lineer } \\
\text { Regresyon }\end{array}$ & 1.3402 & 1.2938 & 0.74 & 0.72 & 1.1061 & 2.6893 & 1.7962 & 1.6739 \\
\hline
\end{tabular}

Önerilen yaklaşımın değerlendirilebilmesi için iki farklı küçük hücre ağı oluşturulmuştur. Her bir küçük hücre ağında periyodik aralıklarla RSSI, SNR ve Jitter değerleri izlenmektedir. Bu HO metriklerinin her iki küçük hücre için benzetim süresince değişimi Şekil 6 ve Şekil 7'de verilmiştir. RSSI -45 ile -140, SNR 0 ile 50, Jitter 10 ile 180 değer aralıklarında rastgele olarak üretilmektedir. 


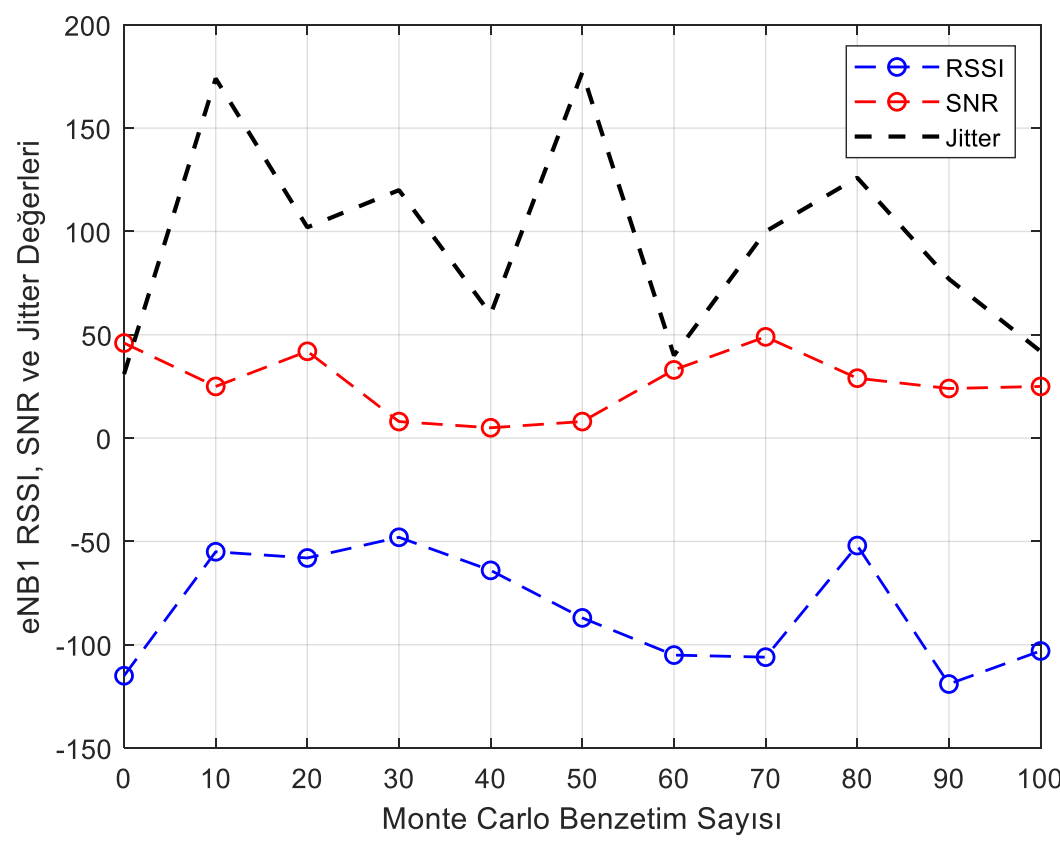

Şekil 6. Küçük hücre (eNB1) için elde edilen HO metrik değerlerinin değişimi

Şekil 6 ve Şekil 7'de RSSI, SNR ve Jitter parametrelerinin değişimi, hem belirli bir hızda sürekli hareket halinde olan mobil kullanıcılardan hem de kapsama alanı küçük olan çok sayıda küçük hücrelerin yerleştirilmesinden kaynaklanmaktadır. Aşırı yoğun ağ senaryolarında beklenen bu sonuçlar beraberinde HO işleminin gereksiz olarak sıklıkla gerçekleşmesine ve servis kalite gereksinimleri açısından başarım göstergelerinin düşmesine sebep olmaktadır. Elde edilen bu sonuçlar bize makine öğrenmesinin HO sürecinde kullanılmasının gerekliliğini göstermektedir.

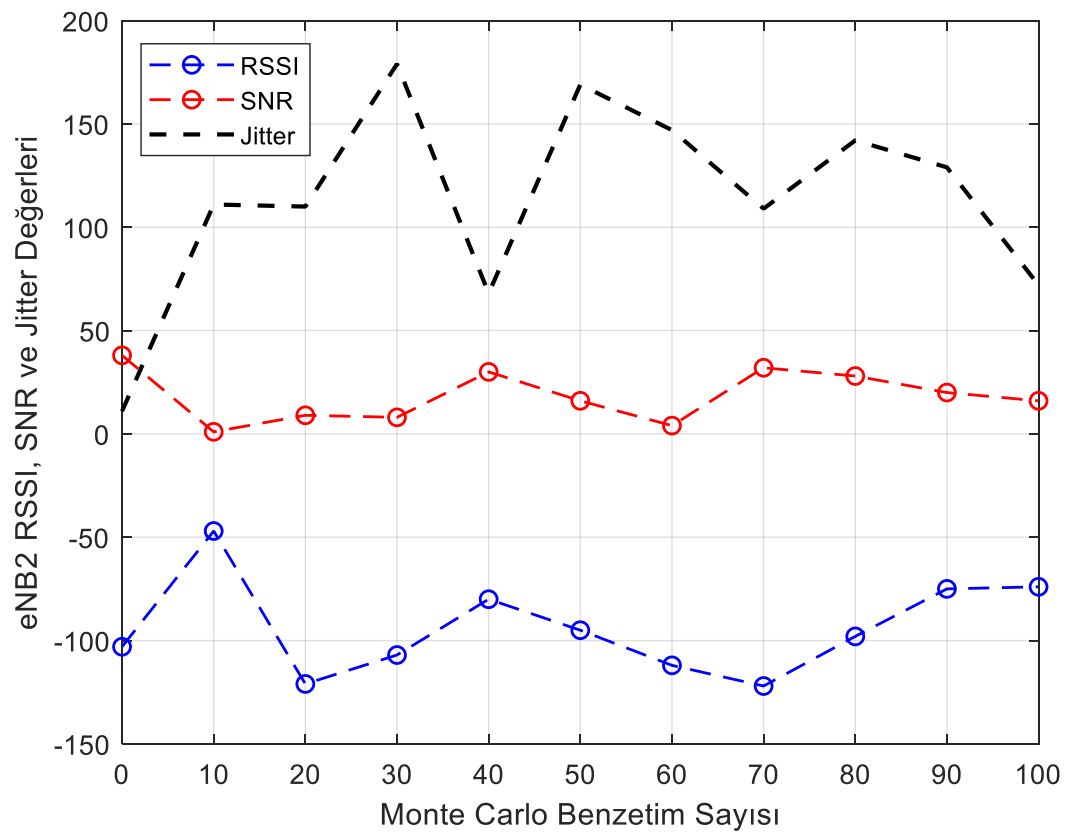

Şekil 7. Küçük hücre (eNB2) için elde edilen HO metrik değerlerinin değişimi 
Şekil 8'de ise küçük hücrelerin RSSI, SNR ve Jitter metriklerine göre eğitilmiş LSTM ağ modeli sonucunda elde edilen adaylık değerlerinin benzetim süresince değişimini gösterilmektedir. Sonuçlar incelendiğinde aşırı yoğun ağ ortamlarında hareketlilik gereksinimlerinden dolayı ortaya çıkan HO parametrelerindeki sürekli değişim eğitilmiş LSTM ağ modeli ile tahmin edilmiştir. Elde edilen bu tahminler birer adaylık değeri olarak ortaya çıkmaktadır. Bu adaylık değerleri geleneksel HO mekanizmalarında olduğu gibi önceden tanımlanmış bir eşik değeri üzerinden değerlendirilerek HO kararlarının gerçekleştirilmesi sağlanabilir. Bu bağlamda eğitilmiş LSTM ağ modelinin aşırı yoğun ağ ortamlarında kullanılması birçok anlamda oldukça getiri sağlayacaktır.

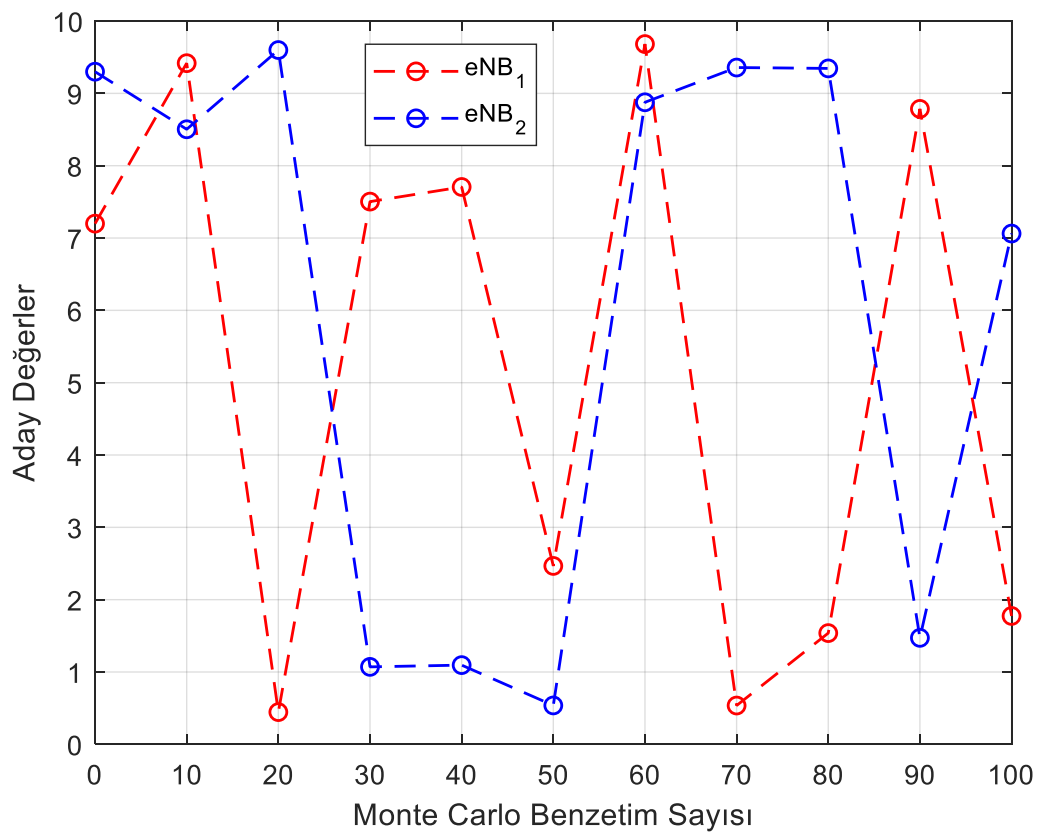

Şekil 8. Küçük hücrelerin LSTM ağ modeli sonucu elde edilen aday değerleri

\section{SONUÇLAR}

Bu çalışmada 5G küçük hücre ağlarında HO kararlarının önceden tahmin edilebilmesine imkan sunacak makine öğrenmesi modeli olan LSTM sinir ağı geliştirilmiştir. Modelin eğitimi için Riverbed Modeler benzetim yazılımında gerçekleştirilen senaryolar aracılığıyla yeni bir veri seti oluşturulmuştur. Daha sonra MATLAB yazılımında LSTM, SVM, Tree ve Lineer regresyon algoritmaları bu veri seti kullanılarak eğitilmiştir. Bu eğitim sonucunda elde edilen istatistiki veriler, LSTM derin sinir ağının diğer regresyon algoritmalarına nazaran başarılı olduğunu göstermektedir. LSTM için eğitilen modelin test sonuçları incelendiğinde; $\mathrm{R}^{2} 0.94$, MAE 0.3315 , MSE 0.3670 ve RMSE değeri 0.6058 olarak bulunmuştur. Bu sonuçlar RSSI, SNR ve Jitter değişkenleri kullanılarak LSTM sinir ağı ile 5G küçük hücre ağlarında HO kararlarının başarılı bir biçimde önceden tahmin edilebileceğini göstermektedir. Gelecek çalışmalarda, geliştirilen model kullanılarak HO yönetiminin benzetim ortamlarında başarımının değerlendirilmesi ve yazılım tanımlı ağ yaklaşımı kullanılarak merkezi ve dağıtık ağ senaryolarının karşılaştırılması planlanmaktadır.

\section{KAYNAKLAR}

[1] Çalhan, A. \& Cicioğlu, M. (2020). Handover scheme for 5G small cell networks with non-orthogonal multiple access. Computer Networks, 183, 107601.

[2] Cicioğlu, M. (2020). Performance Analysis of Handover Management in 5G Small Cells, Computer Standard \& Interfaces, 75, 103502.

[3] Muirhead, D., Imran, M. A. \& Arshad, K. (2016). A Survey of the Challenges, Opportunities and Use of Multiple Antennas in Current and Future 5G Small Cell Base Stations, IEEE Access, 4, 2952-2964. 
[4] Ericsson. (2020). Ericsson Mobility Report. https://www.ericsson.com/4adc87/assets/local/mobilityreport/documents/2020/november-2020-ericsson-mobility-report.pdf (accessed Dec. 10, 2020).

[5] De Ree, M., Mantas, G., Radwan, A., Mumtaz, S., Rodriguez, J. \& Otung, I. E. (2019). Key Management for Beyond 5G Mobile Small Cells: A Survey, IEEE Access, 7, 59200-59236.

[6] Small Cell Forum. (2014). Small cells - what's the big idea? Femtocells are expanding beyond the home. https://scf.io/en/documents/030_-_Small_cells_big_ideas.php (accessed May 24, 2020).

[7] Bilen, T., Canberk, B. \& Chowdhury, K. R. (2017). Handover Management in Software-Defined Ultra-Dense 5 G Networksç IEEE Network, 31(4), 49-55.

[8] Çeken, C., Yarkan, S. \& Arslan, H. (2010). Interference aware vertical handoff decision algorithm for quality of service support in wireless heterogeneous networks. Computer Networks, 54(5), 726-740.

[9] Çalhan, A. \& Çeken, C. (2012). An Optimum Vertical Handoff Decision Algorithm Based on Adaptive Fuzzy Logic and Genetic Algorithm. Wireless Personal Communications, 64(4), 647-664.

[10] Fan, C., Li, B., Zhao, C. \& Liang, Y.-C. (2020). Regret Matching Learning Based Spectrum Reuse in Small Cell Networks. IEEE Transactions on Vehicular Technology, 69(1), 1060-1064.

[11] Xie, J., Yu, F. R., Huang, T., Xie, R., Liu, J., Wang, C., \& Liu, Y. (2018). A survey of machine learning techniques applied to software defined networking (SDN): Research issues and challenges. IEEE Communications Surveys \& Tutorials, 21(1), 393-430.

[12] Alawe, I., Ksentini, A., Hadjadj-Aoul, Y. \& Bertin, P. (2018). Improving traffic forecasting for 5G core network scalability: A machine learning approach. IEEE Network, 32(6), 42-49.

[13] Luo, C., Ji, J., Wang, Q., Chen, X., \& Li, P. (2018). Channel state information prediction for 5G wireless communications: A deep learning approach. IEEE Transactions on Network Science and Engineering, 7(1), 227-236.

[14] Aljeri, N. \& Boukerche, A. (2019). A two-tier machine learning-based handover management scheme for intelligent vehicular networks. Ad Hoc Networks, 94, 101930.

[15] Zeljković, E., Slamnik-Kriještorac, N., Latré, S. \& Marquez-Barja, J. M. (2019). ABRAHAM: machine learning backed proactive handover algorithm using SDN. IEEE Transactions on Network and Service Management, 16(4), 1522-1536.

[16] Sun, Y., Jiang, W., Feng, G., Klaine, P. V., Zhang, L., Imran, M. A. \& Liang, Y. C. (2020). Efficient handover mechanism for radio access network slicing by exploiting distributed learning. IEEE Transactions on Network and Service Management, 17(4), 2620-2633.

[17] Alpaydin, E. (2014) Introduction to Machine Learning Ethem Alpaydin. MIT press, Cambridge, Massachusetts, ABD, 616.

[18] Akgün, D. (2020). An Evaluation of VGG16 Binary Classifier Deep Neural Network for Noise and Blur Corrupted Images. Sakarya University Journal of Computer and Information Sciences, 3(3), 264-271.

[19] Şenturk, Ü., Polat, K. \& Yücedağ, I. (2019). A Novel Blood Pressure Estimation Method with the Combination of Long Short Term Memory Neural Network and Principal Component Analysis Based on PPG Signals. In The International Conference on Artificial Intelligence and Applied Mathematics in Engineering, 20-22 April, Antalya, Turkey, 868-876.

[20] Çavuşlu, M. A., Karakuzu, C., Şahin, S., \& Yakut, M. (2011). Neural network training based on FPGA with floating point number format and it's performance. Neural Computing and Applications, 20(2), 195-202.

[21] Yüzgeç, U., Becerikli, Y. \& Turker, M. (2008). Dynamic neural-network-based model-predictive control of an industrial baker's yeast drying process. IEEE Transactions on Neural Networks, 19(7), 1231-1242.

[22] The Mathworks Inc. (2016). MATLAB - MathWorks. https://www.mathworks.com/products/matlab.

[23] Riverbed Technology. (2020) Riverbed Modeler Software. https://www.riverbed.com/gb/products/steelcentral/steelcentral-riverbed-modeler.html (accessed May 24, 2020). 